\title{
Conclusions
}

\section{Early Greece and the Bigger Picture(s)}

The overall conclusions of this book fall into two broad categories: contributions to our understandings of the archaeology of early Greece and contributions to the broader field of the study of complex societies. In each case I reflect on the place of this book in its wider historical, comparative, and disciplinary contexts, and I follow up with some considerations for future research. The discussions here are meant to be relevant both to archaeologists and historians of Greece and to archaeologists of other complex societies. A final concern has to do with the larger question of why early Greece matters beyond the academic communities to whom the arguments in this book are primarily addressed.

\section{GREECE IN TRANSITION}

A variety of period-specific and historical conclusions can be found in each of the foregoing chapters $(3,4,5$ and 6$)$. Rather than enumerate them here, I focus on two core themes: (1) the long-term perspective concerning the archaeology of central Greece from the Mycenaean period through the Early Iron Age-adding diversity to dominant paradigms through a multiregional approach that seeks comparisons both within Greece and beyond; and (2) the historical-geographical phenomenon of central Greece becoming central-why this transitional period was so important for this particular part of the Mediterranean world.

\section{Diversity through Synthesis and Multiple Modes of Polity}

As a study of ancient Greek social and political landscapes, this book integrates a variety of archaeological evidence across several social and spatial scales. Systematic and unsystematic surveys, long-term research projects, and rescue excavations have all contributed valuable data from some 400 archaeological sites 
(and, among these, thousands of individual findspots). It is only by bringing these data together that we can see how the picture of settlement varies across the different regions under study. This observation is underscored by the amount of recent work on the topic of regionalism (see, e.g., Mazarakis Ainian, Alexandridou, and Charalambidou 2017; Eder 2019; Lemos and Kotsonas 2020). Most individual studies nevertheless focus on a single area or single time period. The long-term, multiregional perspective developed here has allowed us to see the shifting mosaic of the early Greek landscape in myriad ways.

Such a lens leads us to question several long-standing paradigms. Some of these have long been the subject of scrutiny, though rarely in a systematic, diachronic way. These include the primacy of Mycenaean palaces as powerful states with extensive territories, notions of global collapse across Greece and the eastern Mediterranean, and the idea of a rebirth or a "Greek miracle" springing out of a stagnant dark age. These are all exaggerated perspectives, but they remain present in general narratives that paint a picture of early Greece with broad strokes. More sophisticated understandings of the social and historical processes surrounding these paradigms are now possible.

Mycenaean palaces have long dominated discussions of the Late Bronze Age. Their visibility in the landscape, extensive architectural remains, elaborate cemeteries, and elite material culture have inspired authors from the time of Homer onward. Linear B gives us insights into the political and economic operation of palaces that are simply not possible for other periods of the early Greek pastindeed, not until after the eighth century BCE. This wealth of evidence concerning the palaces and the places around them, however, is in fact quite limiting when we consider the Mycenaean world as a whole. The Peloponnesian paradigm suggests that palaces in Messenia and the Argolid (and most recently Laconia) developed quickly at the end of a long Early Mycenaean period in which monumentality gradually shifted from family tombs to a central administrative structure, while interaction with neighboring civilizations intensified and political authority shifted from charismatic individuals to institutions. This is a fairly standard narrative of state formation that can be observed in several parts of the world. The central Greek case, however, shows something quite different. State formationthat is, the development of palaces-seems to have happened much more quickly in central Greece, after the Peloponnese, and only in certain areas. The evidence for palaces themselves is limited to LH IIIA2 and onward, while monumental tholos tombs appear in only two places beforehand (Thorikos and Volos) and only in a handful of locations afterward (Menidi, Orchomenos, etc.) - and all of this after the heyday of tholos tomb building in the Peloponnese. In this way, we seem to have multiple cases of secondary state formation-perhaps also a sort of tertiary state formation or the agglomerative development of peer polities-in which emerging polities only incidentally come onto the scene as actual peers of previously existing palatial centers. 
This process does not happen everywhere, however, and even generous estimates of palatial territory put a large amount of the landscape well outside any likely palatial remit. Our data for all the central Greek palaces is fragmentary, but we might identify regional palatial centers at Thebes, Orchomenos, Gla, and Athens, this last being based on limited and circumstantial evidence. Something different seems to have happened in Thessaly, which may have had two palatial centers - at Palaia (Kastro Volos) and at Dimini-although the relationship between them remains unclear. Other question marks include Krisa in southern Phokis and Kanakia in Salamis. In between the palatial areas of northern Boeotia and Thessaly there is a distance of some 250 kilometers by land as well as several entire regions. These should not be seen as blank spots, or as places that "lacked" a palace, failed to achieve statehood, or otherwise missed the mark. Rather, they contained complex sociopolitical systems in their own right. Significant, if not palatial, centers can be detected in numerous places: in monumental tholos tombs at Medeon (in Phokis) and Georgiko (western Thessaly), with no known palace site nearby; in the upper Kephisos valley and East Lokris; in and around Lamia; in various parts of central Euboea; and in eastern and western Attica. These areas were occupied by people living outside any apparent centralized state, and this was probably quite deliberate. The range of complexity and social organization represented in the (often ambiguous) archaeological record across these areas suggests that we are dealing with complex communities where rank and hierarchy are important but not reified through formal institutions with a high degree of archaeological visibility (see Porter 2013).

A good overall case for comparison can be found in Mississippian chiefdoms, where more and less complex social forms existed side by side and oscillated across the macroregional landscape, and where scholarship has revealed a considerable degree of organizational diversity among contemporary political communities (Blitz 2010). Interactions between Late Woodland groups and Mississippian chiefdoms shed particular light on this issue. In this case, Late Woodland groups adopted particular elements of Mississippian culture, including Cahokian potting traditions, but largely maintained pre-Mississippian modes of social organization (Bardolph 2014). We can see a parallel in this regard with Mycenaean palaces and their interactions with nonpalatial zones, which seem to have been selective in their adoption of elements of palatial material culture. What is more, we should keep in mind that living in a state-with all its labor demands for surplus agricultural production, monumental building, and so on-would have hardly been pleasant or desirable for the vast majority of its subject-inhabitants (Scott 2009).

Based on the evidence of central Greece, we might conclude that if people could live outside the reach of state authority, they would. For most people living most of the time (in early Greece as well as in other predominantly village-based societies), subsistence agriculture was the priority-and one with which states interfered. The central Greek case suggests that Mycenaean states, such as they 
were, did not have a particularly long reach or deep institutional history, making them quite different from their contemporaries elsewhere in the eastern Mediterranean. This also meant that they were unlikely to emerge in a strictly evolutionary course of societal development, as is reflected in the similarity of social formations witnessed before and after the Mycenaean palaces. There was, as a consequence, remarkable variety in the political systems and modes of social organization across Mycenaean central Greece.

The palatial collapse around 1200 BCE was felt most strongly-unsurprisinglyin palatial areas. It is precisely in the modeled territories of Mycenaean palaces that there was a significant drop in settlement numbers, access to prestige goods, and monumental construction, not to mention in administrative systems that only ever existed within palatial contexts. Elsewhere, decreases in site numbers were considerably less extreme (see figure 2). In fact, there seems to be a direct correlation between the level of centralization in the Palatial period and site attrition in Postpalatial times. Boeotia has the most evidence for palaces as centralizing forces, with the Linear B tablets from Thebes and the great drainage works and monumental construction in the Kopaic Basin. This region also had the most substantial drop in site numbers. Athens and Thessaly both saw more modest drops, and indeed seem to have been less centralized in palatial times. At the same time, certain areas that were beyond the apparent influence of the palaces in the Palatial period came to thrive in Postpalatial times, precisely because they did not suffer any kind of sociopolitical collapse. It seems rather that Postpalatial communities-for example, coastal ones at Lefkandi, Kynos, Porto Rafti (Perati, Raftis Island), and Pefkakia-were able to take advantage of the power vacuum left by the disappearance of the palaces. These patterns in central Greece are most apparent in the area of the Euboean Gulf, a trend that reflects a greater amount of human mobility-especially maritime-across the Mediterranean as a whole. Traveling craftspeople, migrant groups, entrepreneurs, and traders emerged out of the breakdown of formalized diplomacy and state-sponsored travel that characterized much of the Late Bronze Age eastern Mediterranean. The age of mobility that followed happened in the wake of significant social reorganization after the decline of palatial systems.

The maritime orientation of Postpalatial times has echoes in chieftaincies in Scandinavia, and in other parts of the world, in what Ling, Earle, and Kristiansen (2018) call a maritime mode of production. Shared interests in trading and raiding are reflected in iconography, the material record, and the ethnohistoric record, especially in situations in which decentralized societies operated on the margins or in the wake of more centralized political systems. While such a maritime mode of production is apparent in some parts of the Postpalatial world (e.g., along the Euboean Gulf), there is significant continuity in the complex communities of other areas (e.g., in the Spercheios and northern Kephisos valleys), which in the previous period were nonpalatial. So, while comparative cases signal 
dynamic societal trajectories in some cases, there remains a significant amount of resilience in others.

Regional diversity continues to characterize our evidence for settlement and society in central Greece into the Prehistoric Iron Age. While the overall number of sites in Attica reached its nadir during this period, Athens itself seems to have flourished, both in terms of its physical extent and its influential pottery industry. On the opposite end of the study area, in Thessaly, settlement expanded considerably, as can be seen especially through funerary architecture-the small tholoi characteristic of the region in the Early Iron Age-which represents a significant and widespread set of references to the Bronze Age past. Continuities from Mycenaean times are also evident in various parts of Malis and Phokis, especially in the remarkable chamber tomb cemeteries of the Spercheios valley and Elateia. It was during this period as well that central Euboea continued to develop as the prime example of Postpalatial emergence in the wake of Palatial collapse. As at Athens, pottery production played a major role, and it can now be demonstrated that the clay quarries of central Euboea were a common link to many parts of central Greece, eventually extending throughout the Aegean and beyond (Kerschner and Lemos 2014). While new scientific evidence has put emphasis on the Early Iron Age, stylistic influence was already present in the Postpalatial Bronze Age. In this case, we do seem to have a gradual, perhaps even linear, expansion in the distribution and then the influence of Euboean ceramics, operating in tandem with Athenian influence, which started later but eventually became much stronger. The Euboean Gulf was especially important as the maritime conduit through which many of these sociotechnological interactions flowed. The arrival of iron technology in central Greece, too, is evidence of significant connections to the eastern Mediterranean, most likely to Cyprus, a long-term point of connection for early Greece. The concentration of early iron artifacts in central Greece, especially in the emergent centers of Athens and Lefkandi, signal their importance as nodal points in networks of changing pyrotechnologies, which must also be related to their uncharacteristically rich records of settlement and burial wealth, as well as to apparent levels of social inequality at the time.

There was a great infilling of settlement in the eighth century, both in the landscapes of central Greece and in various other parts of the Mediterranean. The political landscape was increasingly mediated by local shrines and regional sanctuaries. Decreasing distances between settlements meant closer and more frequent interactions between them, which decreased the necessity for longer-distance excursions and concentrated greater attention on particular parts of a landscape or region. Longer-distance interactions were still maintained intermittently at interregional and eventually panhellenic sanctuaries. At the same time, growth within communities and shrinking distances between them introduced new stresses, which seem to have resulted in community fissioning, even as aspects of local and regional identity were being reified across the landscape (Small 2019). This type of 
fissioning is well documented in other village societies (McGuire and Saitta 1996; Blitz 1999; Bandy 2004), but the distances and maritime orientation of the Greek case is significant and would have had dramatic effects in expanding the geography of evolving Greek notions of identity and polity.

The eighth-century establishment of Greek settlements overseas followed a long history of earlier activities in Italy and in the eastern Mediterranean from the Mycenaean period onward. Greek craftspeople, at least, and probably permanent populations too, were established much earlier throughout western Anatolia and in Cyprus, as well as in Italy. The "first" Greek colonies in Italy are therefore a historical rather than an archaeological phenomenon, but one that was nonetheless significant, since apoikiai did spur changes in Mediterranean settlement that are also manifest in the archaeological record. The leading role of Euboeans is important, and it is coincident with a variety other activities with apparent nexuses in central Euboea, including the adaptation of the Phoenician script into the Greek alphabet and its subsequent dissemination, as well as some record of disturbance at home, perhaps in relation to a mythohistorical Lelantine war. Monocausal explanations for overseas settlement that have to do with land hunger and population growth seem not to obtain, as increases in site numbers are in fact rather marginal in places like Euboea, while Boeotia and Athens see the greatest growth and did not seem to have played a major role in overseas settlement. More complex political processes like local conflict, social fissioning, expanding long-distance trade networks, and targeted procurement of resources are perhaps more appropriate explanations. At the same time, climatic volatility and agricultural uncertainty may have contributed to the development of new settlement strategies, including territorial consolidation or the establishment of new communities elsewhere, on regional or microregional scales.

By the end of the eighth century, we have a blueprint for the Archaic Greek world. Independent polities are evident across central Greece in the form of communities that would develop into historically known poleis; other regions followed different paths of sociopolitical complexity to become federated states or ethne, following the pattern of regional diversity in sociopolitical organization that characterized previous periods as well (see, e.g., Morgan 2003; Hansen and Nielsen 2004; Papadopoulos 2016a). These processes would not come to fruition, however, until the seventh and sixth centuries. There does not seem to have been an ur-period of polis formation, at least not in the eighth century, where poleis all over the Greek world pulled themselves up by their bootstraps on roughly equal footing. Rather, there are eighth-century episodes of community florescence, not unlike the emergence of Mycenaean palaces in that they are limited to particular regions and circumstances. The difference is that the networks and structures introduced in the eighth century-including writing and regional sanctuaries-eventually led to the wider dispersal of polis institutions in the centuries that followed.

In the long term, mutual development happened in the context of regional and interregional interactions, but there was rarely, if ever, some form of even 
evolution across all regions of the Greek world. Oscillations in relative importance and influence characterize central Greece from the Mycenaean period through the eighth century. While a general characterization of nonlinear development obtains across the region as a whole, the most consistent factor is diversity. The emergence of poleis with stronger, codified institutions across the seventh and sixth centuries represents a significant phase transition that signals the end of early Greece, which is characterized by village societies and examples of more and less complex communities.

\section{Central Greece Becomes Central}

While the core datasets of this book are derived from the archaeological landscapes of central Greece, much of the discussion has referred to early Greece in general, or to the place of early Greece in the wider Mediterranean world. There are two reasons for this blended approach. On the one hand, central Greece has been subject to less synthetic treatment than other regions, most notably the Peloponnese. On the other hand, the regions investigated here collectively came to play a leading role in the development of the early Greek world during precisely this period. Between Thessaly and Attica, and including Euboea, we see several social and material phenomena emerge that highlight the importance and centrality of this geographical zone.

I argued in chapter 2 that central Greece occupies a dual crossroads, with the Euboean Gulf serving as a key maritime axis linking the north and south Aegean and the Kephisos valley and Great Isthmus Corridor serving as crucial land routes between northern and southern Greece. We can see glimpses of this already in the Early and Middle Bronze Age, when Manika in central Euboea and Eutresis in southwestern Boeotia become centers of interregional pottery and obsidian consumption in spite of their geographical distance from source areas and trading partners such as the Troad and Melos (Goldman 1931; Sampson 1985, 1988). These geographical considerations are borne out in later periods as well, with Homer's designation of Aulis as the mustering point of the Achaians and Delphi serving as the notional center of the world (and of Mediterranean politics).

The Mycenaean world might be seen as the earliest demonstrably "Greek" period of history in the Aegean, based on its connection to a more literate Early Iron Age through an oral tradition, which looked back to an "age of heroes" that was important for later aspects of collective identity formation. At the same time, aspects of Greek religion are first traceable in the names of later divinities in the Linear B tablets, providing further aspects of continuity across the Bronze Age/ Iron Age divide. Such continuities may extend much further, but they at any rate seem to go through an important period of crystallization in a core area that-during the period covered by this book-includes central Greece and the Peloponnese, along with many parts of the Aegean islands. So, while diversity is ubiquitous, the connective opportunities allowed by central Greece as a geographical center signal this macroregion as an important hub in the dispersal of 
material culture, language, and religion that would culminate in later ideas of Panhellenism. If one imagines, then, a network of places that can be considered "early Greek," whether for archaeological, religious, or mythological significance, central Greece becomes increasingly central from the end of the Bronze Age to the eighth century BCE.

This increasing centrality can also be observed on the wider scale of Mediterranean affairs. Interactions between Aegean societies and their neighbors are less civilizational in emphasis and scope than they are dialogues between particular centers. Networks of consumption of eastern exotica are focused first on the Minoan palaces of Crete, most notably Knossos, and then shift northward to the Mycenaean palaces, with Mycenae by far outpacing the rest and eventually Thebes arriving on the scene (Cline 1997; Burns 2010; Murray 2017). As discussed in chapters 3 and 4, this record may be somewhat skewed; but, based on the currently available evidence, the pattern is clear (compare maps 13 and 17). Palatial period centralization is followed by Postpalatial dispersal, most notably to previously nonpalatial areas; this reflects broader patterns of decentralization in eastern Mediterranean trade and consumption in the twelfth century BCE. By the Protogeometric period, import evidence, though paltry, is found primarily in central Greece (eight sites), there being comparably less such evidence in the Peloponnese (four sites) (compare maps 17 and 23). While the Peloponnese experiences some recovery in Geometric times, especially at Olympia and Sparta, greater concentrations of imports can still be found in central Greece (see map 30). These patterns track broadly with the apparent activities of different parts of central Greece in the north Aegean, in the eastern Mediterranean, and eventually in the central Mediterranean-most notably through the wide dispersal of Athenian and Euboean pottery and, eventually, through Euboean settlements. While this summary is not intended as an argument for the preeminence of one region over another, it does demonstrate the utility of examining societal development on multiple spatial scales, based on layered notions of collective identity that include social groups operating in individual communities, regions, or culture areas.

\section{Prospects and Potential}

The archaeology of early Greece is a rich and active field of scholarship. Work in central Greece is increasingly brought to the fore by a variety of recent regional conferences and companion volumes, evincing a trend that makes the sort of synthesis presented here possible (see, e.g., Mazarakis Ainian, Alexandridou, and Charalambidou 2017; Lemos and Kotsonas 2020; Middleton 2020). I hope that this book will encourage further work at levels above the individual project, site, or region. Such a study also offers the opportunity to reflect on what is missing and to speculate about exciting prospects for future work. To my mind, these prospects fall into three main categories: (1) increased deployment of new techniques in the analysis of archaeological materials; (2) the orchestration and publication of new 
fieldwork in a variety of contexts; and (3) participation in a wider variety of world archaeological dialogues.

A central concern of Mediterranean archaeology remains mobility and migration, especially for the Bronze Age and Early Iron Age (see, e.g., van Dommelen and Knapp 2010; Hamilakis 2016; Molloy 2016; Driessen 2018; Iacono 2019). How much were people moving around and in what capacity were they doing so? To what extent did migration occur on a large scale? How did populations intermingle in such circumstances? How do we understand the circumstances in which migration took place? These questions have been addressed primarily through the analysis of material culture in both ancient and modern contexts. Archaeogenetics and DNA studies have long presented exciting ways forward in the analysis of human, animal, and plant remains (see, e.g., Renfrew and Boyle 2000). Such approaches have proved particularly exciting in analyzing the dispersal of early farmers across Europe, having traced a more or less direct path of migration and the diffusion of agriculture from east to west that was largely maritime (Hofmanová et al. 2016). Recent examples of DNA studies concerning the Aegean Bronze Age have been somewhat overstated, however, in their capacity to address wider questions, focused as they are on the analysis of a few samples from a handful of places (Lazaridis et al. 2017). The potential of such analyses, however, lies in their application over a wide, spatially and temporally diverse dataset. The application of such analyses to human remains from a variety of excavated sites and from a systematically selected sample of contexts would provide important insights into regional and interregional patterns of genetic diversity over time and address how changes in genetic makeup corresponded (or not) with material culture change. A wide sample would provide a novel macroregional, multiscalar dataset that could be integrated into studies of long-term social change. Up until this point, the cost of sample processing has prohibited such widespread programs; but, as the analysis of ancient DNA becomes more commonplace, costs of analysis are already dropping. The design and the permissions to carry out a study of such scope remain barriers but ones that are hopefully surmountable. Fortunately, such large-scale studies are currently in the works-with a new, multidisciplinary European Research Council Grant, for example. ${ }^{1}$

Provenience studies have long offered insights into the movement of materials, and thereby patterns of production and consumption (see, e.g., Knapp and Cherry 1994). As with DNA studies, provenience studies in specific cases provide new insights concerning regional ceramic traditions and their dispersal on multiple scales. The most recent example relevant to this book is the application of neutron activation analysis to Euboean or Euboean-like ceramics from multiple contexts around the Mediterranean (Kerschner and Lemos 2014). On its own, however, a

1. The project is funded by an ERC Consolidator Grant, directed by Molloy. For more information, see The Fall 1200 BC, accessed December 8, 2020, http://www.thefalli2oo.eu/. 
study of pottery from a single region is limited. If we apply such methods in the context of other regional ceramic traditions, in a diachronic framework, the picture may become more complex and yield new insights into regional dynamics rather than simply the interregional reach of one or a few ceramic traditions.

Another growth field is radiometric dating. Improved C-14 calibration allows for increased chronological refinement, while at the same time accelerator mass spectrometry (AMS) techniques are able to deal with smaller samples. These are dependent on excavated contexts, however, and the survey data on which much regional evidence is based remains largely confined to stylistic dating of surface ceramics. As AMS techniques improve, we might be able to see applications that are able to date artifacts directly-for example, charcoal fragments within the fabric of coarse wares or preserved in metal slags. One obvious opportunity of increased chronological resolution is the capacity to look at synchronisms, which continue to occupy a key disciplinary space when considering things like the Late Bronze Age "collapse" in the eastern Mediterranean, as well as other site destructions and events to which the archaeological record might bear witness. Related, of course, are the issues of environmental studies and ancient climate, fields witnessing constant refinement in their own right and for which higher resolution dating is essential.

The collection of new archaeological data through fieldwork and the analysis of unstudied material are the best and most obvious means of expanding, testing, or challenging the arguments and interpretations posed here. As discussed in chapter 2, the analysis of the archaeological landscape on which much of this book is based draws on data from a variety of sources. Different types of fieldworkunsystematic and systematic surveys, research and rescue excavations-yield fundamentally different results, unevenly distributed across the landscape. Sites and communities for which we have a wealth of systematically collected data are in the minority. For the majority of sites included in the overall analysis, therefore, we have to rely on varying degrees of inference and projection. These are informed projections, to be sure, and based on careful consideration of the available evidence, but in the end inferences and interpretation can be made with much greater certainty for some sites than for others.

Ongoing fieldwork at numerous sites will continue to refine our understanding of the early Greek world, both in central Greece and beyond. Recent publications concerning Thebes, for example, shed light on this important mega-center of the Mycenaean world, even though excavations are by nature spottily interspersed across the modern city (Aravantinos and Kountouri 2014). Ongoing projects at Gla and in the Kopais have equally exciting implications, although our knowledge of Orchomenos remains comparatively paltry. The recent publication of excavations at Dimini, too, are promising (Adrimi-Sismani 2017, 2018), and will be even more significant when work from Kastro Volos and Pefkakia reaches final publication (though see Batziou-Efstathiou 2015 and Skafida et al. 2016 for recent summaries). In the Peloponnese, new discoveries concerning the elite cemetery of Pylos offer promising insights for Early Mycenaean times (Davis and Stocker 
2016; Stocker and Davis 2017). At the same time, the Mycenaean palace at Aghios Vasileios, near Sparta, discovered in 2007 and under excavation since then, provides yet another example of diversity in Mycenaean palatial architecture and organization (Kardamaki 2017).

From the Postpalatial period and Early Iron Age several major sites await final publication (e.g., Kynos, Lefkandi, Mitrou). Recently published work on the Early Iron Age of Athens offers an important resource, not least in providing a frame of reference for Attic pottery found widely distributed in other contexts (Papadopoulos and Smithson 2017 Dimitriadou 2019). In-progress research and publication at all these sites will provide significant insights concerning the arguments of this book.

The greatest opportunity for growth, however, concerns fieldwork in sites and landscapes that have not heretofore been subject to systematic investigations. Most parts of the study area examined in this book are covered by gazetteers; many have been extensively surveyed; all have registers of archaeological sites with the local ephorates of the Hellenic Ministry of Culture. However, systematic regional coverage remains quite uneven (see map 3). Areas of particular importance for future regional work include those with major and secondary centers in which very little systematic survey has been conducted: northern and central Euboea; much of Phokis; southern Thessaly; and various places in the vicinity of Lamia. Numerous microenvironments in any of these regions could benefit from more detailed attention, especially around major or secondary centers that promise more complex settlement patterns. For example, in several locations, especially in Malis, a large community in the Mycenaean period can be inferred based on cemetery remains, but no settlement is as yet known. Intensive regional survey work is also likely to answer questions concerning sites that appear to be relatively isolated in the overall settlement pattern. The amount and the variety of recent and ongoing survey work in eastern Attica is particularly encouraging (see table 3).

In the wider world of early Greek settlement patterns, large-scale sites are (for the most part) reasonably well known and investigated. Yet there is a dearth of systematic excavation projects at medium-sized and small sites, as well as at some large, but less well-known sites, such as Stephanovikeio Petra in Thessaly or Aghios Ilias in Euboea. Work in Boeotia offers good models, with surveys of hinterlands and excavations at secondary centers to complement longer-term work at major sites, most notably through the work of the Boeotia Project, the Eastern Boeotia Archaeological Project at and around Eleon, and of the Archaeological Reconnaissance of Uninvestigated Remains of Agriculture (AROURA) and the Mycenaean Northeast Kopais (MYNEKO) projects in the Kopaic Basin and at the secondary centers of Aghios Ioannis and Aghia Marina Pyrgos (e.g., Bintliff, Howard, and Snodgrass 2007; Bintliff et al. 2017; Lane et al. 2016, 2020; Burke et al. 2020). While sites with known, substantial remains are natural targets for excavation, the discipline as a whole would benefit from devoting more attention to excavations at sites documented only from surface remains. A more complete understanding 
of early Greek settlement patterns can only be obtained through more systematic study of sites of a variety of different scales.

\section{COMPARATIVE INSIGHTS FROM EARLY GREECE}

What can comparativists do with early Greece? This question is challenging because the archaeology of early Greece comes with a good deal of disciplinary baggage. For American anthropological archaeologists it falls generally in the broader domain of classical studies, or of classical archaeology more specifically. For archaeologists of Greece, comparison is rarely an explicit aim (though see, e.g., Bajema 2017a, 2017b; Small 2017; Whitley 2020). There are several reasons for this. The first and most straightforward is that it has not historically been a disciplinary priority. The second has to do with the practicalities of research. There is a huge bibliography on the archaeology of Greece, and it exists in several different languages, including English, French, German, and Modern Greek. Italian, Albanian, Turkish, and Bulgarian may be important as well, depending on one's interests. An equally deep and dense literature exists for the various cultures with which Greece was in contact in the wider Mediterranean world. There are therefore significant challenges at the level of basic bibliography, both for the Mediterraneanist to "keep up" and for the comparativist to engage in the first place.

For the very reason that it has often been left out of comparative dialogues, the case of early Greece has much to tell us on a number of fronts. Renfrew (1980) pointed out 40 years ago that the long history of research and the comparatively rich datasets make the ancient Mediterranean a good testing ground for broader theories concerning complex societies. This potential, however, remains largely unrealized. Rather than Mediterranean archaeologists offering up our data to archaeologists working in other parts of the world, it may perhaps be better to do the work on this end and present our research in frameworks and in terms that can transfer easily into other world archaeologies. This is what I have attempted to do in this book. Indeed, the early Greek case can contribute particularly to several underrepresented fields in the study of complex societies. Interactions between state and nonstate societies, cultures comprised of several small polities, and social complexity in ranked, transegalitarian, or village societies are only a few examples (on specific comparisons of the Maya with Mycenaean Greece and Greek city states, see also Tartaron 2008, 132-34; Small 2017). I highlight two areas in which the case study presented here has something explicit to offer: (1) the nonlinear development of societies-secondary state formation, collapse and decline, societal oscillation, cyclical patterns, boom and bust cycles; and (2) archaeologies of protohistory-how archaeologists integrate rich, but highly varied, concatenations of archaeological and textual evidence to arrive at complex understandings of the human past. I then turn to some potential future directions and areas of importance for the archaeology of complex societies. 


\section{Nonlinearity and Social Complexity}

The case for regionalism outlined in the foregoing chapters is also a case of nonlinear development in complex societies. While the neoevolutionary days of bandtribe-chiefdom-state narratives are now well behind us, there remains a great imbalance between the amount of literature that deals with the formation or emergence of social complexity (especially state formation) and the amount dealing with its dissolution. This is not to say that studies of disintegration among complex polities have been completely absent, and indeed the Aegean has been a leader in this regard. Several scholars have sought to address this problem, specifically in the case of the prehistoric Aegean, through discussions of cycling and oscillation (see, e.g., Bintliff 1997; Whitley 2004; Philippa-Touchais 2011). Nonlinearity is a feature of complex systems that has been applied in archaeology since the early work of Clarke (1968) and Renfrew (1972). The explication of specific examples of nonlinear dynamics is rarer.

Part of the reason early Greece is often left out of dialogues concerning complex societies is that there are few obvious cases for comparison. The poleis of the Archaic and Classical periods often feature in broader discussions of early cities or city-states (see, e.g., Morris 1997a; Morris and Knodell 2015). Yet the early Greek polis does not, in fact, compare well at all with other early city-states, especially when one considers their small scale and the unstratified, distributed nature of political power (Whitley 2020). Mycenaean palaces, too, do not have good parallels among other early states, and they feature more often in comparative discussions of collapse than in discussions of state formation or operation (see, e.g., Middleton 2017a). The architectural scale is rather small, territories are minimal, and there is no evidence for ruler iconography or for divine kingship, both of which are major features of emergent states (Kirch 2010, 5-6; Bennet 2018). Moreover, the smaller-scale societies that came before and after have even fewer clear comparisons, and they are cast most often in the loose mold of chiefdoms or caught up in trying to define leadership based on later textual references to basileis (see, e.g., Wright 1995, Crielaard 2011b; Pullen 2011a, 2011b; Kõiv 2016). If we change our perspective slightly, based on the diversity seen in the early Greek settlement pattern and the modes of social organization, we might find better points of comparison-or mutually interesting case studies-in the looser modes of political organization discussed throughout this book through the lens of village societies and complex communities. Early village societies (Bandy 2004; Bandy and Fox 2010), tribal societies (Parkinson 2002), intermediate societies (Arnold 1996), or chiefdoms (Earle 1997; Pauketat 2007) all offer frameworks for studying human social organization that seem to have much more in common with Late Bronze Age and Early Iron Age Greek society than do Archaic states (Feinman and Marcus 1998; Trigger 2003). One thing that the early Greek case has to offer here is a sociopolitical landscape in which different "levels" or modes of sociopolitical complexity seem to operate simultaneously. That is to say, variation in settlement 
hierarchy does not necessarily mean political hierarchy. More often, and as I have shown in the foregoing chapters, it probably signals different modes of community and landscape organization-most notably with respect to palatial and nonpalatial areas in the Palatial Bronze Age, on the one hand, and to the difference between certain principal sites (like Kynos, Lefkandi, and Athens) and most other places in the Postpalatial Bronze Age and Prehistoric Iron Age, on the other.

State formation is dealt with briefly in chapters 3 and 6 , although the emphasis throughout this book has been on sociopolitical reformation and nonstate entities. There is nevertheless something significant here to offer to comparative considerations of secondary state formation, which Fried (1960, 713; 1967, 240-42) distinguished from primary state formation based on influences from other, more complex polities (see also Price 1978). Detailed case studies in secondary state formation exist for early India (Seneviratne 1981), medieval North Africa (Boone, Myers, and Redman 1990), the Levant (Knauf 1992; Joffe 2002), Nubia and Egypt (Smith 1998), early China (Schelach and Pines 2006), and the Aegean (Parkinson and Galaty 2007). Since the 1960 s and 1970s, however, there has been little attempt at large-scale comparison or synthesis in secondary state formation as a topic of anthropological interest. The early Greek case offers an example of the reemergence of political complexity that is different from others in three respects: (1) Archaic Greek city-states are completely different from the Mycenaean palaces; (2) these city-states emerged out of ranked, but not highly stratified, social orders; and (3) the political communities are exceptionally small (Whitley 2020, 179). I suspect such variety is not so rare, but in a comparative sense has gone mostly unnoticed.

It should be no surprise that researchers in the Mediterranean have often expressed interest in nonlinear, nonevolutionary narratives of complexity (see, e.g., Terrenato and Haggis 2011). Studies of cultural influence, especially those that concern more "advanced" societies, are ubiquitous in the field of classics-from the study of Near Eastern influences on early Greek poetry to Horace's notion of Graecia capta. ${ }^{2}$ The roles of emulation and learning from other cultural groups have always been at least implicit in studies of secondary states. The postformation trajectories of secondary states have been less frequently compared. The Aegean offers several opportunities. Elements of Mycenaean statehood can be traced to other societies (most notably Minoan Crete) but as a whole the system was not very successful, lasting only a couple of hundred years (at best). The early Greek polis, by contrast, was extremely successful, lasting-alongside and often within other political formations-well over a millennium (Hansen and Nielsen 2004). Comparison within and beyond the Aegean may offer insights into such fundamental differences in societal trajectories (Blanton and Fargher 2008; Bajema 2017b).

2. Graecia capta ferum victorem cepit et artes intulit agresti Latio (Horace, Epistles 2.1.156): "Greece, captured, took captive her savage victor and brought the arts to rustic Latium." On early Greek poetry, see West's The East Face of Helicon (1997). 
Sherratt (2001) has suggested "Potemkin palaces" as a model for Mycenaean polities, a provocative framework that suggests an aspirational quality in which elements from other states were poorly grafted onto a Mycenaean political system. While "aspiration" and "grafting" may or may not be appropriate terms, the model does invite some telling scalar comparisons between Mycenaean palaces and their eastern Mediterranean neighbors. Mycenaean palatial societies were quite small-scale in comparison to the other polities of the Late Bronze Age eastern Mediterranean. It is also not clear that they were in regular, direct competition with anyone beyond each other and the Minoan groups they seem to have superseded in Crete. While Hittite texts suggest that Mycenaeans were an occasional annoyance on the western edges of the Hittite empire, these polities were operating on vastly different scales (see chapter 3, pp. 103-105). Mycenaean polities, as far as we can tell from the Linear B texts, were much more concerned with their immediate surroundings. If long-distance trading and raiding were state activities, they did not make it into the textual record. Nevertheless, Mycenaean polities were certainly aware of and involved with their more stately neighbors. They seem to have drawn on attributes of other states, observed how they functioned, and then adapted them to their own ends (in terms of writing, land management, and taxation). By contrast, emergent Greek polities of the Early Iron Age, particularly those of the eighth century BCE, may have had more in common (and at least more contact with) each other and with neighboring civilizations in a way that normalized the widespread development of state institutions in the seventh and sixth centuries BCE.

Recent research on the emergence of social complexity has opened up to look beyond top-down, evolutionary models dependent on aggrandizers, chiefs, and kings, and turned also toward the development of cooperation as a powerful social force in both state and nonstate societies (Jennings and Earle 2016; Stanish 2017). Such forces might be detected in the early Greek case as well, especially through communal feasting and intercommunity cooperation at regional sanctuaries. While these may be seen as scenes for aggrandizers to reach a wide audience, they are also venues for group formation and cooperation (and these behaviors are not mutually exclusive). In such a context, the secondary formation of very hierarchical states-like Mycenaean palaces-would be a major disruption to previous social norms, which may in part explain their short lifespan. This may also help explain the emergence of regional institutions in nonpalatial areas, perhaps in response to the growth of palaces in neighboring regions. In this way, the less centralized polities that developed into early poleis may have developed more organically and through practices associated with group and community-integrative cooperation.

Narratives of collapse have been especially prevalent in the social sciences, and increasingly so in comparative contexts. Archaeologists, of course, have much to contribute to studies of collapse and to the question of how to approach collapse from a critical perspective (see, e.g., Renfrew 1979; Tainter 1988; Yoffee and 
Cowgill 1988; Schwartz and Nichols 2006; McAnany and Yoffee 2010; O'Brien 2017; Cunningham and Driessen 2017; Middleton 2017a, 2017b; Knodell 2018). The case studies of collapse at end of the Bronze Age are increasingly well documented in the cases of both Minoan Crete and Mycenaean Greece (see, e.g., Driessen 2002; Cunningham and Driessen 2017; Middleton 2017a, 2020; Murray 2017). Of particular interest in the early Greek case is a complex but explainable instance of systems collapse, whereby several factors resulted in the destruction and ultimate rejection of a prevailing political order. While such events are historically contingent, there are common trajectories that make some societies more vulnerable to such things than others. In the Mycenaean case, we have a combination of rapid sociopolitical change, accompanied by rapid growth and development that could not be sustained socially, perhaps also in terms of human ecology-what Tainter (2006) termed an archaeology of overshoot. Early Greece also offers a case study in the archaeology of resilience (Redman 2005; Papadopoulos 2017a; VidalCordasco and Nuevo-López 2021). While significant changes happened at the end of the Palatial Bronze Age, demonstrable continuities can be traced into Postpalatial times and later, many of which extend back to the Early Mycenaean period (Kramer-Hajos 2016), and even beyond. Snodgrass ([1971] 2000, 186) pointed long ago the presence of certain continuities, especially in burial customs, between the Middle Helladic and Protogeometric period. This would not seem odd at all if we simply removed the Mycenaean Palatial period in the middle.

Continuity, change, resilience, and revolution all point to oscillation or cycling rather than to linear development in the societies of early Greece. Such an assertion would probably hold up to scrutiny in most parts of the world, which raises the question of why. Is there something in the fundamental nature of human societies that makes long-term stability difficult? Societal change is obviously historically contingent, but we may be able to see broader patterns in circumstances involving the introduction of rapid change to conservative systems, to relationships with peer polities, or to levels of centralization. Environmental concerns must obtain as well, and in this respect relationships between communities, polities, and land are key. Significant shifts in agricultural regimes-for example, in certain areas at the beginning of the Palatial period-may have resulted in soil depletion and unsustainability, which itself seems to have been a disruptive cycling phenomenon in several early societies (see, e.g., Shennan 2018).

\section{Archaeologies of Protohistory}

Protohistory, in the context of this study, refers to a period in which written texts of historical interest are present but there is no formal conception of writing history as a genre. This is a nonideal term, perhaps, considering the variety of ways in which it is used, often with colonial connotations to refer to people interacting with-but on the margins of-text-producing cultures (Papadopoulos 2018; see also Schmidt and Mrozowski 2013 on "the death of prehistory" and the historical 
baggage of this term). Here, I am more interested in the capacity of "protohistory" to articulate a certain kind of in-betweenness, both disciplinary and in terms of societal trajectories. All the periods under study in this book might be considered protohistoric in a disciplinary sense. Writing was used in and around early Greek societies, in different ways, throughout the Late Bronze Age and Early Iron Age. Even in "prehistoric" phases, Greece was on the geographical margins of textproducing societies; from a chronological perspective, later Greek texts refer to events that are meant to have happened in prehistoric times. This protohistoric character is perhaps strongest in the eighth century, making it a defining quality of the period, even if the moniker might apply to other times as well. The term is therefore meant to capture the vagueness, variety, and incomplete nature of the scattered textual and other nonmaterial records of potential relevance for the periods dealt with in this book. In the context of the archaeology of complex societies, protohistory puts a name on the middle ground between prehistory and history, which describes real interfaces between peoples with texts and without them, and which provides a framework for considering what different types of early societies do, as well as how we study them.

For two of the four periods covered in this book, Greek textual records exist but do not purport to record history as a deliberate account of past events and behaviors. Some, but not many, people in Greece used writing in the Palatial Bronze Age and in the Protohistoric Iron Age. Later texts refer to the periods in between, both directly and as conflations of societal behaviors from several centuries, as is the case in Homer. For narrative history, in the early Greek world, we begin with

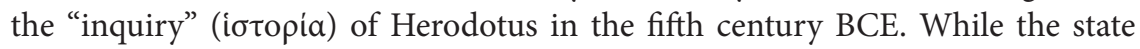
of textual evidence is certainly not ideal, it would be a mistake not to consider it alongside the archaeological evidence, or to leave one or the other out of our interpretations completely. At the same time, of course, the historical record is limited and can rarely be taken at face value. Early Greece therefore offers an important case study for disciplinary considerations of the relationship between archaeology and text, and between prehistory and history.

Such disciplinary issues are not unique to early Greece. The Classic Maya are most frequently compared with ancient Greek city states, going back to Renfrew's (1986) original formulation of peer-polity interaction (see also Sabloff 1986; Small 2017). While differences between these groups are significant-most noticeably in terms of internal political organization and how texts are used-the multipolity regional dynamics, which involve constant competition, warfare, and alliance forming, make such a comparison more valid for the poleis of the Archaic and Classical periods than those treated in this book. Can such features really be detected, however, in prehistoric (or even protohistoric) societies? The conflicts and statecraft of Classic Maya and Archaic and Classical Greek city states are known almost exclusively from the documentary record. Mayanists have had an ongoing reckoning with this disciplinary disjuncture since the decipherment of 
Maya hieroglyphs drastically transformed our knowledge of Maya social, political, and territorial organization (Garrison 2018; Ek 2020). Some comparative dialogue on the challenges of moving between prehistoric, protohistoric, and historical cultures within a diachronic narrative might therefore be fruitful for Aegean archaeologists and ancient historians, as well as for Mayanists.

Nearly all historical archaeologies must address the question of interface between prehistory and history in some form or another. While this question is most explicitly addressed in North American and Mediterranean contexts, the resonance in others should be clear as well (see, e.g., Tandy 2001; Schmidt and Mrozowski 2013). The Americas prior to European contact offer one of the more obvious points of convergence between prehistoric archaeology and textbased history on either side of a chronological divide. This is of course the case in many colonial contact situations (see, e.g., van Dommelen 1998; Stein 2005; Dietler 2010). In this way, archaeologies of protohistory should also be resonant for archaeologies of colonialism-most notably in considering indigenous forms of knowledge production and cultural memory alongside modern, archaeological, ethnographic, or historical ones.

Several long-standing questions about Homeric society concern the relationship between material and text, what nonhistorical texts and oral traditions tell us about social organization, and the role of the past in the past (see, e.g., Finley 1954; Gottschall 2008; Sherratt and Bennet 2017). Looking outward, a critical approach to protohistory invites explicit considerations of cross-cultural interaction, unequal reference and representation in different textual traditions, and ways to view disparate evidence on an even plane.

Early Greek societies also offer multiple case studies in the adoption and disappearance of writing systems (Bennet 2008; Steele 2017, 2020; Boyes and Steele 2020). Like state formation, the writing in the Aegean originated multiple times, and was largely exogenous in its initial development. There were several ways in which writing systems were developed in Greece. These involved different types of regional, societal, interregional, and intersocietal interactions. The earliest Aegean writing, on Crete, has already drawn analogies to incipient scripts in other contexts-for example in Egypt (Ferrara 2015). Cretan hieroglyphs and Linear A were likely developed in the context of inspiration, if not of direct influence, from other scribal societies. Linear B is another story entirely, this script having been adapted from Minoan Linear A to record the Mycenaean (early Greek) language. The circumstances of this adaptation remain little understood, not least owing to the lack of a plausible decipherment for Linear A (as well as our lack of knowledge concerning the language behind it). Equally relevant are the contributions of Linear A and B to comparative discussions of the disappearance of writing systems, or of script obsolescence (Houston, Baines, and Cooper 2003; Baines, Bennet, and Houston 2008). The replacement of Linear A with Linear B invites a series of questions concerning script prestige, practicality, or political takeover (Bennet 2008), 
while the Postpalatial disappearance of Linear B signals the status of the script as a technology of state authority, which becomes obsolete following the disappearance of such an authority.

The invention of the Greek alphabet as an adaptation of the Phoenician offers yet another example of the adoption and dissemination of early Greek writing-by far the most successful. While there are many open questions concerning the appearance and disappearance of the Aegean writing systems described above, they nevertheless offer valuable cases for comparison concerning (1) the work writing does within particular societies, and (2) how its very presence affects their constitution, operation, and reproduction. Why does the Greek alphabet, for example, last some 28 centuries (and counting) while its linguistic ancestor (Linear B) and alphabetic one (Phoenician) are long extinct? One conclusion reached here is that the proliferation of the Greek alphabet can be explained by (1) the capacity of the script to encode the sound of speech directly; (2) its resulting adaptability to different languages; and (3) the historical circumstances of its appearance, which resulted in its rapid dissemination and eventual entrenchment across disparate communities and cultural groups. The Akkadian language and cuneiform script, as the lingua and scripta franca of the ancient Near East in the Bronze Age, may offer an interesting analogy. Chinese writing is a further parallel as a writing system that has lasted some three millennia and has been adapted to record a number of different Chinese languages, as well as Japanese and Korean (Robinson 2007, 199; Gnadesikan 2009, 57; on broader comparisons between ancient Greece and China, see also Lloyd and Zhao 2018).

A final aspect of protohistory with broad resonance concerns the relationship between texts and mythohistory, in which events, happenings, and information are passed down through oral traditions and eventually recorded by early historians. Questioning the relationship between history and true events is nothing new, especially when it comes to the first Greek historians, Herodotus and Thucydides, the second of whom Cornford (1907) referred to as Thucydides Mythistoricus (Chambers 1991; Papadopoulos 1999, 387-88; Papadopoulos 2018). Moving beyond questions of historical accuracy to cultural significance or meaning is an obvious approach, one long in the purview of literary scholars and mythographers. It is less common to seek to explicate relationships between such narratives and actual past processes, as understood through the material record. The result, even if imperfect and selective, can still provide certain types of insights into past societies and their development, especially as the members of those societies themselves viewed it. Examples are found in this book of cases where contemporary and later written sources support, contradict, or obscure past events and processes. These must be assessed on a case-by-case basis. What we should avoid, however, are broad-brush dismissals or categorical rejections of certain types or bodies of evidence. Even if we conclude that problematic sources tell us nothing about the period of the past they purport to tell us about, they still tell us something about perceptions of 
the past in the past, which are intrinsically valuable considerations for long-term regional history and the mechanisms that drive it. Mobility, migration, conflict, foundation, and abandonment are key themes related to identity creation (and repression) that are resonant-regardless of whether or not they have identifiable material roots. We have little trouble talking about such modes of identity construction and imagined pasts in the context of recent and contemporary societies; protohistory offers a particular framework in which to engage such themes in archaeological contexts as well. And archaeology provides a common lens through which various types and stages of protohistoric societies can be compared.

\section{Future Directions in the Comparative Archaeology of Complex Societies}

The future directions highlighted above for the archaeology of early Greece are chiefly practical. In considering the archaeology of complex societies more generally, our concerns are necessarily more theoretical. Of course, the methodological and practical aspects of how archaeology is done, especially above the level of the individual site, will affect comparative approaches as well, as more data is gathered, published, and available for side-by-side comparison. But the most exciting developments in this realm concern comparative research priorities and how we think about the diversity of human pasts.

Leppard and I have recently reflected on several future prospects for the study of complex societies (Leppard and Knodell 2018). On the one hand, the rapidity of development in media and other technologies for data recording and analysis will continue to affect archaeological research across a variety of scales, most notably large-scale comparative studies that seek to aggregate and analyze large bodies of data. We have also pointed toward methodological flexibility and a diversity of research questions and priorities as a boon for regional studies in particular and the study of complex societies in general. Methodological and theoretical transparency is far more important than narrowly defined comparative approaches that seek to place societies side by side and tick boxes of attributes. In this way I suspect that comparisons are likely to become less global and more focused on particular trajectories or responses to certain problems, such as natural disaster, population growth, or climate change. Serendipity also plays a role. We can predict that advances in archaeogenetics and radiometric dating will have major impacts across nearly all subfields of archaeology, but we must also acknowledge that unlooked for technological innovations or material discoveries have often had transformative effects in shaping archaeological research priorities and agendas. In this way we might look to under-researched areas that are not traditionally the focus of research on complex societies to provide exciting ways forward. Central Asia, Siberia, the Arctic, and sub-Saharan Africa may well have much to offer comparative understandings of social complexity, even if these areas are underrepresented in such research-at least in comparison to the Mediterranean, the 
Middle East, Mesoamerica, and the American Southwest. New research in less thoroughly investigated areas may be particularly important for the study of nonstate modes of sociopolitical complexity.

In 2014 several prominent archaeologists published a paper on 25 "grand challenges for archaeology," based on the results of a survey distributed by several professional organizations for archaeologists, chiefly in North America and Europe (Kintigh et al. 2014). The survey stipulated that these challenges needed to be problems that were "solvable" or at least "addressable" through the use of empirical evidence (Kintigh et al. 2014, 7). The 25 challenges all relate to issues of culture process and coupled human and natural systems. It is no coincidence that addressing these challenges is a major research priority for the US National Science Foundation. These challenges revolve around five sets of themes: (1) emergence, community, and complexity; (2) resilience, persistence, transformation, and collapse; (3) movement, mobility, and migration; (4) cognition, behavior, and identity; and (5) human-environment interactions. I have outlined above (and in the foregoing chapters) the significance of several of these, both in general and in the early Greek case. There is no doubt that all present exciting avenues for future research in a variety of disciplinary and geographical contexts. I would speculate that the most important of these for future research and growth is human-environmental interactions. While this is a long-standing area of research in nearly all subfields of archaeology, there has already been a recent surge in interest in topics like human responses to natural disasters and climate change. As archaeology continues to follow interests and issues facing contemporary society, we might expect more work specifically on large and small-scale agricultural economies - and other aspects of food production and subsistence-in response to changing environmental circumstances. Somewhat underdeveloped in this list are questions of identity formation, imagined communities, ideology, and nonrational decision-making. While these last points are certainly more difficult to study empirically, their significance in shaping collective human behavior has been made more apparent than ever in the last decade, and across the globe.

A final potential growth area is public archaeology. This concerns interfaces between archaeologists and stakeholders in the communities in which they work, as well as the capacity of archaeology to contribute to public discourse. The grand challenges of Kintigh and other scholars (2014) were largely derived from their capacity to address "real-world" problems. But what role do archaeologists really play at the level of contemporary cultural beliefs concerning the past and its role in the present? What impact does archaeology (especially academic archaeology) have in the policy decisions of modern nation states? If our goals and challenges are to address questions of broad relevance, we must also address the challenge of reaching the right audiences. Scholarly audiences are aware of the need for context and nuance in interpreting the past, as well as in the ways that the material vestiges of the past have been (mis-)appropriated in political and ideological 
agendas. But we must now do a better job of confronting the challenge of making scholarship based on real research and expertise more relevant than sensationalist accounts of the "glories of the ancients" or the more sinister or racist messages of Ancient Aliens and various attempts to whitewash the classical world. As a field, archaeology is increasingly aware of these concerns. Granting agencies require statements of broader significance for research and often carry a mandate for open-access publication or writing for popular audiences. In practice, however, nonacademic publication has not traditionally been a priority for academic archaeologists, not least because the professional rewards are low and the risks (or at least the investment of time) can be quite high. This has begun to change as archaeologists consider public education and outreach-both of which are chiefly carried out through blogs, websites, online journals, and public presentations in local communities-a disciplinary priority or even an obligation. We might expect these efforts to grow in future years, and in tandem with broader academic and societal interests in social justice, inequality, and the over-exploitation of natural resources. We can hope that growing interest in these matters has a positive effect, but we should also seek more active and aggressive advocacy from archaeologists with expertise in relevant fields.

\section{WHY EARLY GREECE MATTERS}

I wrote this book during a period of considerable discord in parts of the world traditionally associated with "Western" civilization. Concepts of crisis and collapse are invoked regularly in reference to global markets. People talk about clashes of civilizations in an increasingly globalized world. Political upheavals have dramatically transformed long-standing institutions. Climate change is increasingly dangerous and disruptive. A pandemic has ravaged global health, with catastrophic consequences for social and economic life as well. In the background, technological change-most of all concerning media and interconnectivity-exaggerates and perpetuates such social transformations. While I do not draw direct analogies between ancient and modern societies, it is no coincidence that the themes highlighted in this book are what they are. These are issues that all human societies must grapple with. The early Greek case is particularly relevant here as the frequently cited "foundation" of "Western" civilization. Whether such a characterization has merit or not, it is a long-standing cultural phenomenon that requires scrutiny and explanation.

So, what light does an archaeology of early Greece shed on the contemporary world? Studying the trajectories of past societies allows us to see patterns and processes that are not always apparent in the present. By highlighting them in scholarship, we might better recognize where we are in our own societal trajectories; or we might at least enhance our awareness of what factors influence them. In bringing this book to a close I look at a few of these patterns and their modern relevance. I 
also look at the differences between the past realities of early Greek societies and historical and contemporary perceptions of them. The latter, I think, have had a more powerful effect on the modern world, and not always for the good.

One pattern that seems evident in both the early Greek case and in other complex adaptive systems is that societies are most fragile when they become highly centralized (see also Yoffee 2019). By contrast, political formations are more stable, if less comparatively powerful, when they are one of many, similarly sized systems. This is evident throughout the period treated in detail in this book-most acutely in the Mycenaean palaces but also in emergent centers like Lefkandi during the Postpalatial Bronze Age and Early Iron Age. The long-term lesson seems to be that periods of preeminence in wider systems are likely to be short term and punctuated by periods of upheaval. While scholars (and nonscholars) sometimes point to ancient Egypt as a hallmark of long-lasting cultural traditions and social institutions, Egypt was in fact characterized by long periods of instability and rupture, stemming from both internal and external forces. In spite of terminological critiques or calls for more nuanced explanations for culture change, societies do "collapse" - that is to say, they undergo rapid, fundamental transformation, which affects the ways and quality of life for large populations, often for the worse. Such phenomena typically follow periods of dramatic change in the nature of social complexity and inequality. The Mycenaean palaces rose quickly, not gradually, through dramatic transformations in the centralization of political and social power. While such transformations represented rapid pathways to power, these were also socially destabilizing forces that ultimately were not sustainable.

In various parts of this book I have argued that Greece has played a relatively minor role in the modern anthropological study of complex societies. There is no question, however, of the foundational role of "ancient Greece" in contemporary understandings of "civilization" or "the West." These conceptions have their roots in understandings of ancient Greece that formed the background of early anthropology and evolutionary models of the development of ancient societies. There is a predominant view of Greece as special in the history of Europe-an ur-civilization to which "the West" owes a particular debt (Hanink 2017). In the postcolonial, global world of the twenty-first century, there is a well-established need to critique notions of "Western" primacy. There is therefore also a need to critique the roots of such a narrative, which are in the European colonial projects of the sixteenth to nineteenth centuries. Early anthropology and ideas about how human societies (both ancient and modern) should be studied and classified were major parts of these projects. There was a fundamental difference between the ways in which colonial Europeans saw themselves and the ethnographic societies on which classifications of chiefdoms and tribes were built. As European states encountered these groups, they had to describe them in terms that were categorically different from their own social formations. Europe was seen as a world of states, whereas many parts of the colonial world were not. The ancient Greeks, so the reasoning 
went, were the literary and cultural forebears of Rome and Europe, and so must also have been more complex, "civilized" social formations. Europeans, including cultural historians, had the dual goal of making early Greek society (1) a demonstrable forerunner to their own; and (2) on par with or superior to the ancient civilizations of contemporary colonial or "oriental" zones.

A significant legacy of Eurocentrism is that, for all the periods under examination in this book, there has been a tendency in the scholarship to overstate the relative scale of early Greek societies in comparison with their neighbors in the eastern Mediterranean. This can in part be tied to the place of Greece in the "Western" imagination, and especially to the spectacular discoveries of the late nineteenth and early twentieth centuries regarding the prehistory of the region. The ability to connect the imagined, mythological past of Greece with material remains was powerful, even if the observed remains were recognized as having little to do with the world constructed in later myths and legends. Nevertheless, the thrill of discovery surrounding "Europe's first states" in the form of Minoan and Mycenaean civilizations put these societies on a particular kind of pedestal, which has been entangled with the identities of both Greek and Western European nation states ever since (Voutsaki 2017; see also Hamilakis 2007; Hanink 2017). This inceptive Greek/European imaginary has obscured our understanding of early Greek societies among their contemporaries, as well as in comparison to other complex societies.

Likewise, in the Early Iron Age, there has been a tendency to look to the eighth century as a revolutionary moment when the spark of Hellenism spurred the democratic political formations of the early Greek polis and spread them throughout the Mediterranean. This is what Small (2015) has called the "false narrative" of early Greek political development-a teleology culminating in classical Athens, which obscures the really quite varied range of sociopolitical formations and trajectories present in early Greece, as well as their contemporary significance (see also McInerney 1999, 9; Morgan 2003). This diversity deserves attention intrinsically, but broader trends can be highlighted by a comparative perspective that examines both societies with which Greek polities were in contact and other societies that have experienced similar paths of development.

It is worth making explicit the connections between early Greece and contemporary, global culture, in which "Western" civilization is a significant identity marker and magnet for assertions of cultural eminence. Such ideological touchstones, which mean so many different things for as many different groups, should be highlighted for careful thought and critique. One aspect of this critique-at least as presented in this book-is to expose certain myths concerning the societies of early Greece: ages of heroes, Europe's first states, fonts of democracy, and the like. Such things may have been present in early Greece in some way or anotherat least they were in the ancient Greek imagination-but we should not let this obscure the fact that many equally rich (and often more sophisticated) cultural 
and political traditions evolved in Africa, Asia, and the Americas. We should not lose sight of the fact that Hellenism (and philhellenism) grew out of pro-European colonial projects, which, incidentally, were often anti-Modern Greek (Hanink 2017). This is not meant to disparage or undervalue the importance of studying ancient Greece, but rather to underscore the fact that Greek society (and the study of it) never developed in a vacuum; moreover, the pride of place it has been given in historical thought is a historical phenomenon worthy of study in and of itselfone that is essential to consider in any attempt to understand early Greece.

As I write this, I have just finished teaching a first-year undergraduate seminar on "The Trojan Legend: Mythology, Archaeology, and Legacy." The ten-week course covers the Homeric epics, the archaeology of Troy and the Mycenaean world, the world of Homer, and-more and more significantly, to my mind-the legacies of the Trojan Legend through its depictions and retellings in literature, art, and performance from fifth-century Athens to the present day. As is our custom, the discussion topic for the final day turned to the broad question of why the Trojan Legend matters, which of course is directly related to the equally broad question of why early Greece matters (see also Vermeule 1986).

Discussions of significance necessarily involve some form of critique. In the present day it is hard not to read the Iliad and see its protagonists as hypermasculine, petty, squabbling narcissists. In the material record we see evidence for competitive display and social inequality, on the one hand, and village societies mostly concerned with everyday subsistence, on the other. From the cultural context of a small liberal arts college in the Midwestern United States there is not much to recommend Homeric society as a set of moral guidelines. But should we try to understand it? Of course. We see reflections of these behaviors recurrently in "Western" history, often with explicit reference to early Greek, Homeric, or classical ideals. Such unified ideals are regularly sourced to some generic Greek or classical past that almost certainly never existed. Early Greece seems rather to have been comprised of a diverse political and cultural landscape in almost constant flux. This is a pattern that obtained in the Classical period as well. While democratic Athens (when it was democratic) may have provided some building blocks for modern democracies, Greece was still a world of tyrannies and oligarchies, many of which fell under the thumb of Athens, which may have been a democratic polis but was also a brutal and hegemonic empire. This simple history matters not least because it offers the opportunity to examine singular notions of the past and the real role they play in contemporary politics.

The period covered in this book-from the Mycenaean world to the ages of Homer-witnessed the codification of notions of Greekness and, from there, "Western" identity that would last some three millennia. These notions are hardly static, and indeed have been adapted continually over the centuries. The protohistoric "moment" of early Greece is nevertheless an important cultural touchstone that is too easy to see as uniform, and it is often caught up in contemporary 
politics of self-definition, intentionally or not. It is therefore well worth recognizing the significance of this past and interrogating what we actually know about it through its material remains and its associated textual traditions. The early Greek past reveals a diversity of modes of social organization, political formations, and types of cross-cultural interactions. For a world that has a history of looking at "the West" in contrast to notional "others," it is important to point out this contradiction in terms. One takeaway, perhaps, is that at face value the perceived European and American heirs of classical civilization have very little in common with early Greek societies, at least in terms of social and political values and organization. It matters also that we understand why and how we have come to think and say we do. We should not hold up the past as virtuous based solely on a connection we feel to it. Rather, we should critique these connections and the elevated positions we attribute to them.

If we look to the early Greeks for our own cultural roots, we must first acknowledge that early Greece exhibited a wealth of diversity across space and time. Second, these societies were defined by much wider sets of relations between different communities and cultures, which played out over a variety of social and spatial scales. Finally, we should note that these groups manipulated and deployed their own pasts in a variety of ways, especially in terms of defining themselves and others. Such characteristics can probably be observed in nearly all complex societies. What role this knowledge of past human behavior can play in our own local and global communities remains a pressing question. 